described two cases of bacterial meningitis in sportsmen who took part in sporting activities within a week of symptoms suggesting influenza; one of the patients died." Sutton et al described a 42 year old patient who died from heart failure after swimming. Coxsackie virus B4 was isolated from damaged myocardial tissue. ${ }^{5}$

Inquiry about recent minor illness should be standard practice in athletes with unexplained loss of form. It may also be worth considering a viral cause, as infections that are subclinical in the normal population may greatly affect maximum performance in athletes. Athletes with such infections might be tempted to increase their training load when a temporary reduction would be more appropriate.

1 Sprunt TP, Evans FA. Mononuclear leukocytosis in reaction to acute infection 2 Arnold DL, Boe PJ, Radda GK, Styles P, Taylor DJ. Excessive intracellular acidosis of skeletal muscle in a patient with post viral exhaustion/fatigue acidosis of skeletal muscle in
syndrome. Lancet $1984 ;$;i:1367-9.

3 Hamblin TJ, Hussain J, Akbar AN, Tang YC, Smith JL, Jones DB. Immunological reason for chronic ill health after infectious mononucleosis. Br Med $\mathcal{J}$ $1983 ; 287: 85-8$

4 Pether JVS. Bacterial meningitis after influenza. Lancet 1982;i:804.

Sutton GC, Harding HB, Trueheart RP, Clark HP. Coxsackie B4 myocarditis in an adult: successful isolation of virus from ventricular myocardium. Aerospace

Accepred 7 November 1984)

Department of Respiratory Medicine, Western Infirmary, Glasgow G11 6NT

J A ROBERTS, BSC, MRCP, medical registrar and medical adviser to the Scottish Amateur Athletic Association

\section{Tamoxifen as primary treatment of breast cancer in elderly or frail patients: a practical management}

Tamoxifen is the most widely used agent in hormonal treatment of advanced breast cancer. It may have a role as primary treatment for elderly or frail patients who are unfit for surgery or primary radiotherapy.

\section{Patients, methods, and results}

In 1977 we started using tamoxifen ( $10 \mathrm{mg}$ thrice daily) instead of surgery as primary treatment for elderly or frail patients with histologically confirmed breast cancer. We report on the first 100 patients (mean age 76.3 years; 11 weeks (range 6-135). Median duration of tamoxifen treatment was 23 months in patients with a complete response (range 5-48), 18 months in patients with a partial response (range 6-55), and 15 months in the group showing no change. Two patients with a complete response and 10 with a partial response subsequently relapsed, giving a median duration of response of 19 months (mean 24 months, range 9-55); four received breast irradiation, two were given aminoglutethimide, and six did not receive any further treatment. In 10 patients the disease progressed during treatment.

Oestrogen receptor state was determined in 37 patients, 35 of whom had concentrations $\geqslant 20 \mathrm{fmol} / \mathrm{mg}$ cytosolic protein-that is, were rich in receptor. The proportion of these patients who responded $(74 \%)$ was similar to the proportion overall. The median oestrogen receptor concentration was 300 fmol/mg cytosolic protein. Patients with locally advanced $\left(T_{4}\right)$ disease responded less well. Side effects to tamoxifen occurred in 33 patients: dry mouth (13 patients), fatigue (10), transient nausea (10), vomiting (four), vaginal dysaesthesia (two), and vaginal discharge (two). One patient stopped treatment because of persistent nausea. Fourteen deaths occurred: six due to vascular disease in responders, and three due to vascular disease and five to disseminated carcinoma in non-responders.

\section{Comment}

Elderly patients with breast cancer can create problems in management when primary surgery or radiotherapy is considered to be inappropriate. Results of using tamoxifen as primary treatment have been encouraging in terms of response rates and possibly survival. ${ }^{2} 3$ The response rate in this study $(68 \%)$ compares well with that in previous reports. The similar response in patients rich in oestrogen receptor and those whose receptor state was unknown suggests that such tumours in the elderly should be regarded as rich in oestrogen receptors.

We emphasise the slow time to response (median 15.5 weeks). The actuarial survival of our patients at five years was $52 \%$ compared with $42 \%$ (not significant) in a historical control group of elderly women treated by surgery or irradiation. Only five of the 14 deaths were due to carcinoma, and these were among non-responders. Tamoxifen was well tolerated by the patients: only one third experienced side effects, which were generally transient.

We believe that tamoxifen is an excellent and appropriate primary treatment for elderly women with breast cancer.

We thank Dr R A Hawkins for performing the oestrogen receptor assays, which are supported by a grant from the Cancer Research Campaign.

1 Hayward JL, Carbone PP, Heuson JC, Kumaoka S, Segaloff A, Rubens RD. Assessment of response to therapy in advanced breast cancer: a project of the programme on clinical oncology of the Intern

2 Preece PE, Wood RAB, Mackie CR, Cuschiera A. Tamoxifen as initial sole treatment of localised breast cancer in elderly women: a pilot study. Br Med $\mathcal{F} 1982$; 284:869-7W.

Bradbeer JW, Kyngdon J. Primary treatment of breast cancer in elderly women

Influence of oestrogen receptor state and size of tumour on response to treatment with tamoxifen

\begin{tabular}{|c|c|c|c|c|c|c|c|c|}
\hline \multirow[b]{2}{*}{ Response } & \multirow[b]{2}{*}{$\begin{array}{c}\text { No of } \\
\text { patients }\end{array}$} & \multicolumn{3}{|c|}{ Oestrogen receptor state of patient } & \multicolumn{4}{|c|}{ Size of tumour } \\
\hline & & Unknown & Rich* & Poor & $\begin{array}{l}\leqslant 2 \mathrm{~cm} \\
\left(\mathrm{~T}_{1}\right)\end{array}$ & $\begin{array}{c}>2-5 \mathrm{~cm} \\
\left(\mathrm{~T}_{2}\right)\end{array}$ & $\begin{array}{l}>5 \\
\left(T_{3}\right)\end{array}$ & $\begin{array}{c}\text { Locally } \\
\text { advanced }\left(T_{4}\right)\end{array}$ \\
\hline $\begin{array}{l}\text { Complete } \\
\text { Partial } \\
\text { No change } \\
\text { Progressive disease }\end{array}$ & $\begin{array}{l}39 \\
29 \\
22 \\
10\end{array}$ & $\begin{array}{r}23 \\
19 \\
15 \\
6\end{array}$ & $\begin{array}{r}16 \\
10 \\
7 \\
2\end{array}$ & 2 & $\begin{array}{l}1 \\
1\end{array}$ & $\begin{array}{r}19 \\
11 \\
4 \\
3\end{array}$ & $\begin{array}{l}9 \\
3 \\
1 \\
1\end{array}$ & $\begin{array}{r}10 \\
15 \\
16 \\
6\end{array}$ \\
\hline Total & 100 & 63 & 35 & 2 & 2 & 37 & 14 & 47 \\
\hline No $(\%)$ responding & $68(68)$ & $42(67)$ & $26(74)$ & 0 & $1(50)$ & $30(81)$ & $12(86)$ & $25(53)$ \\
\hline
\end{tabular}

*20 fmol/mg cytosol protein.

aged $60-69,26$ aged $70-74,35$ aged $75-80$, and 28 aged over 80 ) who received tamoxifen for an indefinite period or until their disease progressed (range five to 55 months). Over the same period 111 elderly patients (75 aged 70-74, 32 aged 75-79, and four aged over 80 ) underwent surgery or radiotherapy; in 1980, however, we began giving primary endocrine treatment to most women over 70 . Thirty eight of the patients studied had other major systemic disorders (for example, vascular disease, arthropathy, and dementia). After biopsy staging was confined to full blood count, tests of liver function, and chest and pelvic radiology. Two dimensional measurements of the tumours were assessed using criteria of the International Union Against Cancer ${ }^{1}$ as indicating partial response, complete response, no change, or progressive disease.

The table shows the response and how this was influenced by the oestrogen receptor state and size of the tumour. Tumour was localised to the breast and axilla in 89 patients. Of 68 patients with objective regression of tumour, 39 had complete resolution. Median time to achieve best response was $15 \cdot 5$
(Accepted 16 November 1984)

University Department of Clinical Oncology, Western General Hospital, Edinburgh EH4 2XU

SIMON G ALLAN, MB, MRCP, lecturer in medical oncology

ALAN RODGER, MB, FRCS, consultant radiotherapist

JOHN F SMYTH, MD, FRCP, professor of medical oncology

ROBERT C F LEONARD, MD, MRCP, senior lecturer in medical oncology

University Department of Clinical Surgery, Royal Infirmary, Edinburgh

UDI CHETTY, MB, FRCSED, senior lecturer in clinical surgery

A PATRICK M FORREST, MD, FRCR, professor of surgery

Correspondence to: Dr S G Allan. 